\title{
Article \\ Differences in Menstruation-Related Symptoms of University Students Depending on Their Living Status in Japan
}

\author{
Yukie Matsuura ${ }^{1, *}$, Nam Hoang $\operatorname{Tran}^{2} \mathbb{D}$ and Toshiyuki Yasui ${ }^{1}$ \\ 1 Department of Reproductive and Menopausal Medicine, Graduate School of Biomedical Sciences, \\ Tokushima University, Tokushima 770-8503, Japan; tosyasui@tokushima-u.ac.jp \\ 2 Research Center for Higher Education, Tokushima University, Tokushima 770-8502, Japan; \\ tran@tokushima-u.ac.jp \\ * Correspondence: y.matsuura@tokushima-u.ac.jp; Tel.: +81-88-633-7628
}

check for updates

Citation: Matsuura, Y.; Tran, N.H.; Yasui, T. Differences in

Menstruation-Related Symptoms of University Students Depending on Their Living Status in Japan.

Healthcare 2022, 10, 131. https:// doi.org/10.3390/healthcare10010131

Academic Editor: Susan Letvak

Received: 5 December 2021

Accepted: 6 January 2022

Published: 9 January 2022

Publisher's Note: MDPI stays neutral with regard to jurisdictional claims in published maps and institutional affiliations.

Copyright: (C) 2022 by the authors. Licensee MDPI, Basel, Switzerland. This article is an open access article distributed under the terms and conditions of the Creative Commons Attribution (CC BY) license (https:// creativecommons.org/licenses/by/ $4.0 /)$.

\begin{abstract}
Mothers and family members of young female students play important roles for guiding their self-care strategies for menstruation-related symptoms; which often affect their daily life and academic life. The aim of this study is to clarify the differences in menstruation-related symptoms before and during menstruation in university students living alone and university students living with their family in Japan. We conducted a cross-sectional online survey to assess menstruationrelated symptoms before and during menstruation using the menstrual distress questionnaire (MDQ). Among 135 students; the proportion of students living alone was $60.7 \%$ and the proportion of students living with their family was $39.3 \%$. Before menstruation; the MDQ total score and the scores for negative affect and behavior change were significantly higher in students living alone than in students living with their family. During menstruation; scores for negative affect and impaired concentration were also significantly higher in students living alone. In addition; before menstruation; scores for an increase in appetite and craving for sweets were significantly higher in students living alone. Thus; living alone affected the psychological aspects of menstruation-related symptoms in young women. The results suggest that university students who live alone should be aware of the importance of talking about their menstruation problems with family members and seeking their advice
\end{abstract}

Keywords: menstruation-related symptoms; living status; young women; menstrual distress questionnaire

\section{Introduction}

Menstruation-related symptoms, including premenstrual symptoms and menstrual pain, have various effects on the daily life of young women. A survey conducted in Japanese female high school students showed that premenstrual symptoms impaired "work efficiency or productivity and home responsibility" in 50.7\% of the students, "social life activities" in $23.3 \%$ of the students and "relationships with coworkers or family" in $24.0 \%$ of the students, and that $11.9 \%$ of the students were absent from school for more than 1 day per month due to premenstrual symptoms [1]. A systematic review and meta-analysis of thirty-eight studies in young female school students or university students showed that $20.1 \%$ of the students reported an absence from school or university due to dysmenorrhea, and that $40.9 \%$ of the students reported classroom performance or concentration being negatively affected [2]. Although $50-80 \%$ of women of the reproductive age have at least mild premenstrual symptoms, with $30-40 \%$ of women with premenstrual syndrome (PMS), including 3-8\% of women with premenstrual dysphoric disorder (PMDD) requiring treatment, most women with premenstrual symptoms repress their symptoms without diagnosis or management [3]. Nevertheless, many young women primarily use self-care for their symptoms and their family plays a part in consultation regarding their symptoms. Mothers, together with school nurses and peers, are the key sources for information on 
PMS and reproductive health for Japanese high school students [4]. According to a review and meta-analysis of twenty-four studies, the most common source of information about menstrual symptoms other than medical consultations was the family [5]. For Chinese university students, communication about dysmenorrhea was mainly with their mothers (73.4\% of the students) and friends (79.0\% of the students) [6]. It can be difficult for students to receive support, including information and advice on menstrual symptoms from their family, after starting university and living alone far away from their parents. There have been some studies on the relationship between menstruation-related symptoms and the living status of female university students, but no conclusive results have been obtained. A study conducted in Brazil revealed that menstrual migraine was more frequent in women living together with other students (50\%) than in women living alone (16.7\%) [7]. In another study conducted in Palestine, no relationship was found between the presence of dysmenorrhea and living status, although students living in dormitories had 1.72 odds of having moderate/severe dysmenorrhea compared to students living with their own families [8]. In Japan, a cohort study conducted on university students at three months after admission to university, showed that students living with their families are more likely to have psychological symptoms during menstruation than students living alone, but no difference was found in the premenstrual symptoms between these two groups of students [9]. Although menstrual cycle-related symptoms include physical, behavioral and emotional symptoms [10], there have been few studies focusing on differences in comprehensive symptoms, especially behavioral symptoms, depending on living status, including living alone or living with the family.

Since 2020, the coronavirus disease 2019 (COVID-19) pandemic has resulted in drastic lifestyle changes, including social distancing and travel restrictions. The pandemic has also resulted in negative changes in the lifestyle of university students, including study, sleep and eating habits, and university students have spent more time in front of screens for online education [11]. The pandemic has also affected menstruation-related symptoms. In Ireland, the pandemic has had negative effects on the reproductive health of women, including worsening premenstrual symptoms (53\%) and the appearance of dysmenorrhea $(30 \%)$ [12]. However, there has been no study on menstruation-related symptoms in relation to living status. Therefore, the aim of this study is to clarify the differences in menstruationrelated symptoms before and during menstruation in university students living alone and university students living with their family.

\section{Materials and Methods}

\subsection{Participants}

A cross-sectional online survey was conducted from May to July, in 2021.

The participants were female students majoring in health sciences at a university in Japan. To recruit participants for the study, we conducted an explanation session to a total of 320 students and 169 students agreed to participate.

\subsection{Procedure}

During an online class or face-to-face class, we provided an explanation of the purpose and protocol of the survey and asked students to participate in the survey. The survey was created using the SurveyMonkey ${ }^{\circledR}$ on-line survey tool (https:/ /jp.surveymonkey.com/ accessed on 9 August 2021). We provided the participants the URL and QR code for the survey. On the first page of the web survey, informed consent was obtained by checking the button to agree to participate in the survey, and then the participants continued to answer the questions anonymously. The study was approved by the Ethics Committee of Tokushima University Hospital (approval number: 3932).

\subsection{Measurements}

The questionnaire was developed by the researchers. 


\subsubsection{Demographic and Lifestyle Exposure Measurements}

The questionnaire included questions on demographic factors (grade, age, body weight, body height, age of menarche, currently visiting a gynecologist and receiving hormone therapy); lifestyle (living status, frequencies of eating breakfast and doing exercise, sleeping hours, part-time job, club activities and smoking and drinking habits); rate of online classes and hours spent using smartphone and computers for purposes other than for online classes. We assessed the stress levels of the students for 12 stressors that were selected from previous studies $[13,14]$, including menstrual disorders; physical and health conditions other than menstruation; personality; family relations; relations with friends; romantic relationships; study and academic performance; future prospects; economic conditions; daily life conditions, such as increased housework; part-time jobs and extracurricular activities. The participants rated each item on a 5-point scale from 0 to 4 , with 0 indicating no feeling of stress and 4 indicating severe stress.

\subsubsection{Menstruation-Related Outcome Measurements}

The questionnaire also had questions on present menstrual conditions, including menstrual cycle length and regularity, duration of menstruation and perceived amount of menstrual bleeding, and intensity of menstruation-related symptoms. To assess the degrees of menstruation-related symptoms, we used the menstrual distress questionnaire (MDQ), which is a standard method for assessing cyclical perimenstrual symptoms [15] and also showed Cronbach's alpha coefficient for reliability $[4,16]$. The MDQ has been translated into other languages and has been used in many countries, and there is also a Japanese version. The MDQ includes 46 items for self-reported assessment of symptoms and there are 8 scales: 3 somatic scales for pain ( 6 items), water retention (4 items) and autonomic reactions ( 4 items); another 3 scales for mood and behavioral changes, namely negative affect (8 items), impaired concentration ( 8 items) and behavior change (5 items); and two scales for arousal (5 items) and control (6 items) [17]. We asked students to describe their experience of each symptom during each of the 3 stages of the menstrual cycle: before menstruation (4 days before mensuration), during menstruation and the remainder of the cycle. Each symptom was rated from 0 to 4 , with 0 indicating no experience of the symptom and 4 indicating severe symptom. In this study, the Cronbach's alpha coefficient for total MDQ score before and during menstruation was 0.84 and 0.86 , respectively. In addition, we added three symptoms about eating habits, including an increase in appetite, craving for sweets and craving for snacks, which were shown to be specific changes before and during menstruation in our previous study [18].

\subsection{Statistical Analysis}

Each categorized variable is expressed as a number with percentage or a mean with standard deviation. We divided the participants into two groups based on their living status, including living alone and living with the family. The significance of differences in variables in the two groups was evaluated by the $t$-test, Fisher's exact test or the FisherFreeman-Halton test. The MDQ score was calculated by the total score and score for each of the 8 scales, and each of them is presented as median (25th percentile, 75th percentile) and mean with standard deviation. The Mann-Whitney U test was used to compare total scores of the MDQ, scores of the eight scales and scores of eating symptoms in the two groups. We conducted additional analyses for each item that was found to have a significant difference according to living status, by using the Mann-Whitney U test. All $p$-values less than 0.05 were considered statistically significant. Statistical analyses were conducted using SPSS Statistics version 28.0 for Windows (IBM Corp., Armonk, NY, USA).

\section{Results}

Of the total of the 320 students who were asked to participate, 169 agreed and responded. Among them, we excluded 18 students who had not completed the MDQ items, 10 students who had received hormone therapy because of gynecological diseases, such 
as PMS or dysmenorrhea, and 4 students with missing responses to living status. Among the students, 82 students (59.8\%) were living alone, 53 students (38.7\%) were living with their families, no students were living with friends and 2 students $(1.5 \%)$ were living in a dormitory. We also excluded the 2 students who were living in a dormitory, and data for 135 students were used for analysis.

\subsection{Demographic Data}

The proportions of students living alone and students living with their family were $60.7 \%$ and $39.3 \%$, respectively. There were no significant differences between living status and the grade of students. Body mass index (BMI) for students living alone was significantly higher than that for students living with their family $(p=0.036)$. There were no significant differences between living status and menstrual situations. There was a significant association between living status and frequency of drinking alcohol $(p=0.036)$ (Tables 1 and 2).

Table 1. Demographic characteristics and menstrual conditions depending on living status.

\begin{tabular}{|c|c|c|c|c|c|c|}
\hline \multirow[t]{2}{*}{ Characteristics } & \multirow[t]{2}{*}{ Category } & \multicolumn{2}{|c|}{$\begin{array}{l}\text { Live Alone } \\
\quad(N=82)\end{array}$} & \multicolumn{2}{|c|}{$\begin{array}{l}\text { Live with Family } \\
\qquad(N=53)\end{array}$} & \multirow[t]{2}{*}{$p$-Value * } \\
\hline & & $\mathbf{N}$ & $\%$ & $\mathbf{N}$ & $\%$ & \\
\hline \multirow{4}{*}{ School grade } & 1st year & 42 & 51.2 & 18 & 34.0 & \multirow{4}{*}{0.113} \\
\hline & 2nd year & 12 & 14.6 & 16 & 30.2 & \\
\hline & 3rd year & 14 & 17.1 & 10 & 18.9 & \\
\hline & 4th year & 14 & 17.1 & 9 & 17.0 & \\
\hline Age (years) ${ }^{a}$ & & 19.4 & $(1.4)$ & 20.4 & $(4.7)$ & 0.054 \\
\hline Height $(\mathrm{cm})^{a}$ & & 157.3 & $(4.6)$ & 157.4 & $(5.3)$ & 0.903 \\
\hline Weight $(\mathrm{kg})^{\mathrm{a}}$ & & 52.2 & $(6.7)$ & 50.3 & $(5.6)$ & 0.086 \\
\hline $\mathrm{BMI}\left(\mathrm{kg} / \mathrm{m}^{2}\right)^{\mathrm{a}}$ & & 21.1 & $(2.2)$ & 20.3 & $(1.9)$ & 0.036 \\
\hline $\begin{array}{l}\text { Menarche age } \\
\text { (years) }^{a}\end{array}$ & & 12.1 & $(1.5)$ & 12.0 & $(1.2)$ & 0.574 \\
\hline \multirow{3}{*}{$\begin{array}{c}\text { Menstrual cycle } \\
\text { length }\end{array}$} & 24 days or less & 0 & 0.0 & 2 & 3.8 & \multirow[t]{3}{*}{0.198} \\
\hline & 25-38 days & 75 & 91.5 & 45 & 84.9 & \\
\hline & 39 days or more & 7 & 8.5 & 6 & 11.3 & \\
\hline \multirow{3}{*}{$\begin{array}{l}\text { Menstrual cycle } \\
\text { regularity }\end{array}$} & Regular & 41 & 50.0 & 22 & 41.5 & \multirow[t]{3}{*}{0.101} \\
\hline & Sometimes irregular & 39 & 47.6 & 25 & 47.2 & \\
\hline & Irregular & 2 & 2.4 & 6 & 11.3 & \\
\hline \multirow{2}{*}{$\begin{array}{c}\text { Duration of } \\
\text { menstruation }\end{array}$} & 3-7 days & 78 & 95.1 & 53 & 100.0 & \multirow[t]{2}{*}{0.154} \\
\hline & 8 days or more & 4 & 4.9 & 0 & 0.0 & \\
\hline \multirow{3}{*}{$\begin{array}{c}\text { Perceived amount } \\
\text { of menstrual } \\
\text { bleeding }\end{array}$} & Light & 6 & 7.3 & 5 & 9.4 & \multirow[t]{3}{*}{0.863} \\
\hline & Moderate & 63 & 76.8 & 41 & 77.4 & \\
\hline & Heavy & 13 & 15.9 & 7 & 13.2 & \\
\hline
\end{tabular}

a mean (SD), *t-test, Fisher's exact test or Fisher-Freeman-Halton exact test.

Table 2. Lifestyle characteristics depending on living status.

\begin{tabular}{ccccccc}
\hline \multirow{2}{*}{ Characteristics } & Category & \multicolumn{2}{c}{$\begin{array}{c}\text { Live Alone } \\
(\mathbf{N}=\mathbf{8 2})\end{array}$} & \multicolumn{2}{c}{$\begin{array}{c}\text { Live with Family } \\
(\mathbf{N}=\mathbf{5 3})\end{array}$} & \multirow{2}{*}{$\boldsymbol{p}$-Value * } \\
\cline { 3 - 6 } & & $\mathbf{N}$ & $\mathbf{\%}$ & $\mathbf{N}$ & $\mathbf{\%}$ & \\
\hline & Every day & 36 & 43.9 & 34 & 64.2 & 0.142 \\
Breakfast & 5-6 days a week & 20 & 24.4 & 8 & 15.1 & \\
frequency & 3-4 days a week & 14 & 17.1 & 6 & 11.3 & \\
& 1-2 days a week & 9 & 11.0 & 2 & 3.8 & \\
& None & 3 & 3.7 & 3 & 5.7 & \\
\hline
\end{tabular}


Table 2. Cont.

\begin{tabular}{|c|c|c|c|c|c|c|}
\hline \multirow[t]{2}{*}{ Characteristics } & \multirow[t]{2}{*}{ Category } & \multicolumn{2}{|c|}{$\begin{array}{l}\text { Live Alone } \\
\quad(N=82)\end{array}$} & \multicolumn{2}{|c|}{$\begin{array}{l}\text { Live with Family } \\
\qquad(N=53)\end{array}$} & \multirow[t]{2}{*}{$p$-Value * } \\
\hline & & $\mathbf{N}$ & $\%$ & $\mathbf{N}$ & $\%$ & \\
\hline \multirow{5}{*}{$\begin{array}{l}\text { Average sleep } \\
\text { hours }\end{array}$} & $4 \mathrm{~h}$ & 2 & 2.4 & 1 & 1.9 & \multirow[t]{5}{*}{0.821} \\
\hline & $5 \mathrm{~h}$ & 15 & 18.3 & 8 & 15.1 & \\
\hline & $6 \mathrm{~h}$ & 35 & 42.7 & 19 & 35.8 & \\
\hline & $7 \mathrm{~h}$ & 27 & 32.9 & 23 & 43.4 & \\
\hline & $8 \mathrm{~h}$ & 3 & 3.7 & 2 & 3.8 & \\
\hline \multirow{5}{*}{ Exercise frequency } & Every day & 1 & 1.2 & 1 & 1.9 & \multirow[t]{5}{*}{0.304} \\
\hline & 5-6 days a week & 4 & 4.9 & 6 & 11.3 & \\
\hline & 3-4 days a week & 6 & 7.3 & 7 & 13.2 & \\
\hline & 1-2 days a week & 27 & 32.9 & 18 & 34.0 & \\
\hline & None & 44 & 53.7 & 21 & 39.6 & \\
\hline \multirow{2}{*}{ Smoking } & Yes & 0 & 0.0 & 1 & 1.9 & \multirow[t]{2}{*}{0.393} \\
\hline & No & 82 & 100.0 & 52 & 98.1 & \\
\hline \multirow{3}{*}{ Drinking } & At least once a week & 1 & 1.2 & 4 & 7.5 & \multirow[t]{3}{*}{0.036} \\
\hline & Occasionally & 22 & 26.8 & 7 & 13.2 & \\
\hline & None & 59 & 72.0 & 42 & 79.2 & \\
\hline
\end{tabular}

* Fisher's exact test or Fisher-Freeman-Halton exact test.

Except for 23 fourth-grade students who were receiving training at hospitals, $74 \%$ of the students had taken more than $80 \%$ of their classes online. All of the students used smartphones, and the proportions of students who were using smartphones for more than $6 \mathrm{~h}$ per day were $22.0 \%$ in students living alone and $7.5 \%$ in students living with their family. There was no significant difference in the hours of smartphone or personal computer use between the two groups of students, according to living status.

\subsection{Stress Level}

The stress level of daily life, such as increased housework in students living alone was significantly higher than that in students living with their family $(p<0.001)$, but the stress level of family relations tended to be lower in students living alone $(p=0.096)$ (Table 3$)$.

Table 3. Intensities of types of stress depending on living status.

\begin{tabular}{|c|c|c|c|c|c|c|}
\hline \multirow[t]{2}{*}{ Type of Stress } & \multirow[t]{2}{*}{ Stress Level } & \multicolumn{2}{|c|}{$\begin{array}{l}\text { Live Alone } \\
\quad(N=82)\end{array}$} & \multicolumn{2}{|c|}{$\begin{array}{l}\text { Live with Family } \\
\qquad(N=53)\end{array}$} & \multirow[t]{2}{*}{$p$-Value * } \\
\hline & & $\mathbf{N}$ & $\%$ & $\mathbf{N}$ & $\%$ & \\
\hline \multirow{5}{*}{$\begin{array}{l}\text { Menstrual disorders } \\
\text { (menstruation and } \\
\text { menstruation- } \\
\text { related } \\
\text { symptoms) }\end{array}$} & None & 18 & 22.0 & 12 & 22.6 & \multirow[t]{5}{*}{0.820} \\
\hline & Mild & 19 & 23.2 & 16 & 30.2 & \\
\hline & Moderate & 18 & 22.0 & 11 & 20.8 & \\
\hline & Strong & 16 & 19.5 & 10 & 18.9 & \\
\hline & Severe & 11 & 13.4 & 4 & 7.5 & \\
\hline \multirow{5}{*}{$\begin{array}{l}\text { Physical and health } \\
\text { conditions (other } \\
\text { than menstruation) }\end{array}$} & None & 37 & 45.1 & 27 & 50.9 & \multirow[t]{5}{*}{0.908} \\
\hline & Mild & 28 & 34.1 & 18 & 34.0 & \\
\hline & Moderate & 11 & 13.4 & 6 & 11.3 & \\
\hline & Strong & 4 & 4.9 & 2 & 3.8 & \\
\hline & Severe & 2 & 2.4 & 0 & 0.0 & \\
\hline \multirow{5}{*}{ Personality } & None & 25 & 30.5 & 22 & 41.5 & \multirow[t]{5}{*}{0.394} \\
\hline & Mild & 27 & 32.9 & 15 & 28.3 & \\
\hline & Moderate & 21 & 25.6 & 10 & 18.9 & \\
\hline & Strong & 4 & 4.9 & 5 & 9.4 & \\
\hline & Severe & 5 & 6.1 & 1 & 1.9 & \\
\hline
\end{tabular}


Table 3. Cont.

\begin{tabular}{|c|c|c|c|c|c|c|}
\hline \multirow{2}{*}{ Type of Stress } & \multirow{2}{*}{ Stress Level } & \multicolumn{2}{|c|}{$\begin{array}{l}\text { Live Alone } \\
\quad(N=82)\end{array}$} & \multicolumn{2}{|c|}{$\begin{array}{l}\text { Live with Family } \\
\qquad(N=53)\end{array}$} & \multirow{2}{*}{$p$-Value * } \\
\hline & & $\mathbf{N}$ & $\%$ & $\mathbf{N}$ & $\%$ & \\
\hline \multirow{5}{*}{ Family relations } & None & 66 & 80.5 & 34 & 64.2 & 0.096 \\
\hline & Mild & 10 & 12.2 & 11 & 20.8 & \\
\hline & Moderate & 5 & 6.1 & 4 & 7.5 & \\
\hline & Strong & 1 & 1.2 & 4 & 7.5 & \\
\hline & Severe & 0 & 0.0 & 0 & 0.0 & \\
\hline \multirow{5}{*}{ Friend relations } & None & 46 & 56.1 & 34 & 64.2 & 0.226 \\
\hline & Mild & 27 & 32.9 & 13 & 24.5 & \\
\hline & Moderate & 4 & 4.9 & 6 & 11.3 & \\
\hline & Strong & 2 & 2.4 & 0 & 0.0 & \\
\hline & Severe & 3 & 3.7 & 0 & 0.0 & \\
\hline \multirow{5}{*}{ Romantic relations } & None & 66 & 80.5 & 43 & 81.1 & 0.589 \\
\hline & Mild & 9 & 11.0 & 8 & 15.1 & \\
\hline & Moderate & 4 & 4.9 & 2 & 3.8 & \\
\hline & Strong & 3 & 3.7 & 0 & 0.0 & \\
\hline & Severe & 0 & 0.0 & 0 & 0.0 & \\
\hline \multirow{5}{*}{$\begin{array}{c}\text { Study and academic } \\
\text { performance }\end{array}$} & None & 21 & 25.6 & 15 & 28.3 & 0.961 \\
\hline & Mild & 23 & 28.0 & 15 & 28.3 & \\
\hline & Moderate & 24 & 29.3 & 16 & 30.2 & \\
\hline & Strong & 10 & 12.2 & 6 & 11.3 & \\
\hline & Severe & 4 & 4.9 & 1 & 1.9 & \\
\hline \multirow{5}{*}{ Future prospects } & None & 23 & 28.0 & 13 & 24.5 & 0.585 \\
\hline & Mild & 18 & 22.0 & 16 & 30.2 & \\
\hline & Moderate & 22 & 26.8 & 17 & 32.1 & \\
\hline & Strong & 9 & 11.0 & 3 & 5.7 & \\
\hline & Severe & 10 & 12.2 & 4 & 7.5 & \\
\hline \multirow{5}{*}{$\begin{array}{l}\text { Economic } \\
\text { conditions }\end{array}$} & None & 52 & 63.4 & 38 & 71.7 & 0.412 \\
\hline & Mild & 11 & 13.4 & 9 & 17.0 & \\
\hline & Moderate & 13 & 15.9 & 5 & 9.4 & \\
\hline & Strong & 4 & 4.9 & 0 & 0.0 & \\
\hline & Severe & 2 & 2.4 & 1 & 1.9 & \\
\hline \multirow{5}{*}{$\begin{array}{c}\text { Daily life conditions } \\
\text { (increased } \\
\text { housework, etc.) }\end{array}$} & None & 32 & 39.0 & 42 & 79.2 & $<0.001$ \\
\hline & Mild & 19 & 23.2 & 8 & 15.1 & \\
\hline & Moderate & 25 & 30.5 & 2 & 3.8 & \\
\hline & Strong & 5 & 6.1 & 1 & 1.9 & \\
\hline & Severe & 1 & 1.2 & 0 & 0.0 & \\
\hline \multirow{5}{*}{ Part-time job } & None & 59 & 72.0 & 36 & 67.9 & 0.249 \\
\hline & Mild & 9 & 11.0 & 12 & 22.6 & \\
\hline & Moderate & 7 & 8.5 & 4 & 7.5 & \\
\hline & Strong & 6 & 7.3 & 1 & 1.9 & \\
\hline & Severe & 1 & 1.2 & 0 & 0.0 & \\
\hline \multirow{5}{*}{$\begin{array}{l}\text { Extracurricular } \\
\text { activities }\end{array}$} & None & 67 & 81.7 & 38 & 71.7 & 0.074 \\
\hline & Mild & 10 & 12.2 & 13 & 24.5 & \\
\hline & Moderate & 4 & 4.9 & 0 & 0.0 & \\
\hline & Strong & 0 & 0.0 & 0 & 0.0 & \\
\hline & Severe & 1 & 1.2 & 2 & 3.8 & \\
\hline
\end{tabular}

${ }^{*}$ Fisher-Freeman-Halton exact test.

\subsection{Menstruation-Related Symptoms}

Before menstruation, the MDQ total score and scores for negative affect and behavior change were significantly higher in students living alone than in students living with their family. During menstruation, scores for negative affect and impaired concentration were also significantly higher in students living alone than in students living with their family, 
and the MDQ total score and score for behavior change tended to be higher in students living alone (Table 4).

Table 4. Intensities of Menstrual Distress Questionnaire (MDQ) symptoms in scales depending on living status.

\begin{tabular}{|c|c|c|c|c|c|c|c|c|c|c|c|c|c|c|}
\hline \multirow{3}{*}{$\begin{array}{l}\text { Scales } \\
\text { Pain }\end{array}$} & \multirow{3}{*}{$\begin{array}{c}\text { No. of } \\
\text { Items }\end{array}$} & \multicolumn{7}{|c|}{ Before Menstruation } & \multicolumn{6}{|c|}{ During Menstruation } \\
\hline & & \multicolumn{3}{|c|}{$\begin{array}{l}\text { Live Alone } \\
\quad(N=82)\end{array}$} & \multicolumn{3}{|c|}{$\begin{array}{c}\text { Live with } \\
\text { Family }(N=53)\end{array}$} & \multirow{2}{*}{$\frac{p \text {-Value * }}{0.244}$} & \multicolumn{3}{|c|}{$\begin{array}{l}\text { Live Alone } \\
(N=82)\end{array}$} & \multicolumn{2}{|c|}{$\begin{array}{c}\text { Live with } \\
\text { Family }(N=53)\end{array}$} & \multirow{2}{*}{$\frac{p \text {-Value * }}{0.391}$} \\
\hline & & 3.0 & $(1.8$ & 7.0) & 3.0 & $(1.0$, & $5.0)$ & & 8.0 & $(4.0$ & 12.0) & 7.0 & $(4.0,11.0)$ & \\
\hline $\begin{array}{l}\text { Water } \\
\text { retention }\end{array}$ & 4 & 3.0 & $(1.8$ & 7.0) & 4.0 & $(2.0$ & $7.5)$ & 0.470 & 4.0 & $(1.0$ & $6.0)$ & 3.0 & $(2.0, \quad 6.0)$ & 0.768 \\
\hline $\begin{array}{l}\text { Autonomic } \\
\text { reaction }\end{array}$ & 4 & 1.0 & $(0.0$ & 2.0) & 0.0 & $(0.0$, & $2.0)$ & 0.387 & 2.0 & $(0.8$ & 3.3) & 1.0 & $(0.0, \quad 2.0)$ & 0.150 \\
\hline $\begin{array}{l}\text { Negative } \\
\text { affect }\end{array}$ & 8 & 6.0 & $(1.0$ & 13.0) & 4.0 & $(0.0$ & $8.5)$ & 0.021 & 8.0 & $(2.8$ & 13.0) & 4.0 & $(1.0,9.5)$ & 0.014 \\
\hline $\begin{array}{c}\text { Impaired } \\
\text { concentration }\end{array}$ & 8 & 2.0 & $(0.0$ & 7.0) & 1.0 & $(0.0$ & $4.0)$ & 0.103 & 5.0 & $(1.0$ & 11.0) & 4.0 & $(0.0,6.0)$ & 0.025 \\
\hline $\begin{array}{l}\text { Behavior } \\
\text { change }\end{array}$ & 5 & 3.0 & $(0.0$ & 9.3) & 2.0 & $(0.0$, & $4.0)$ & 0.014 & 7.0 & $(2.0$ & 12.0) & 4.0 & $(1.0,8.5)$ & 0.073 \\
\hline Arousal & 5 & 1.5 & $(0.0$ & $4.0)$ & 2.0 & $(0.0$ & 3.0) & 0.563 & 1.0 & $(0.0$ & $4.0)$ & 1.0 & $(0.0, \quad 3.0)$ & 0.612 \\
\hline Control & 6 & 0.0 & $(0.0$ & 1.0) & 0.0 & $(0.0$ & $1.0)$ & 0.105 & 0.0 & $(0.0$ & $2.0)$ & 0.0 & $(0.0,1.0)$ & 0.092 \\
\hline $\begin{array}{l}\text { Total MDQ } \\
\text { score }\end{array}$ & 46 & 24.5 & $(13.8$, & $50.5)$ & 20.0 & $(9.0$ & $30.0)$ & 0.042 & 38.5 & (20.0, & 56.3) & 29.0 & $(12.0,49.0)$ & 0.057 \\
\hline
\end{tabular}

* Mann-Whitney U test; data are presented as medians (25th percentile, 75th percentile).

We conducted additional analyses for each item in the scales of negative affect and behavior change in the premenstrual phase, and negative affect and impaired concentration in the menstrual phase, which were found to be significantly different depending on living status. Before menstruation, the scores were significantly higher in students living alone than in students living with their family for mood swings $(p=0.007)$ and feeling sad or blue $(p=0.039)$ in the negative affect, and for taking naps and staying in bed $(p=0.004)$, staying at home $(p=0.002)$ and avoid social activities $(p=0.027)$ in the behavior change (data was not shown). During menstruation, the scores were significantly higher in students living alone than in students living with their family for mood swings $(p=0.023)$, crying $(p=0.013)$ and restlessness $(p=0.01)$ in the negative affect, and for distractible $(p=0.001)$ in the impaired concentration (data was not shown).

Before menstruation, scores for eating habit symptoms, including an increase in appetite and craving for sweets, were significantly higher in students living alone than in students living with their family (Table 5).

Table 5. Intensities of eating symptoms depending on living status.

\begin{tabular}{|c|c|c|c|c|c|c|c|c|c|c|c|c|c|c|}
\hline \multirow{3}{*}{$\begin{array}{c}\text { Symptoms } \\
\begin{array}{c}\text { Increased } \\
\text { appetite }\end{array}\end{array}$} & \multicolumn{7}{|c|}{ Before Menstruation } & \multicolumn{7}{|c|}{ During Menstruation } \\
\hline & \multicolumn{3}{|c|}{$\begin{array}{l}\text { Live Alone } \\
\quad(N=82)\end{array}$} & \multicolumn{3}{|c|}{$\begin{array}{l}\text { Live with Family } \\
\qquad(N=53)\end{array}$} & \multirow{2}{*}{$\frac{p \text {-Value * }}{0.013}$} & \multicolumn{3}{|c|}{ Live Alone $(N=82)$} & \multicolumn{3}{|c|}{$\begin{array}{l}\text { Live with Family } \\
\qquad(N=53)\end{array}$} & \multirow{2}{*}{$\begin{array}{c}\boldsymbol{p} \text {-Value * } \\
0.858\end{array}$} \\
\hline & 3.0 & $(0.8$ & $3.0)$ & 1.0 & $(0.0$ & $3.0)$ & & 1.0 & $(0.0$ & 2.0) & 1.0 & $(0.0$ & $2.0)$ & \\
\hline $\begin{array}{l}\text { Craving } \\
\text { for sweets }\end{array}$ & 2.0 & $(1.0$ & $3.0)$ & 1.0 & $(0.0$ & $3.0)$ & 0.013 & 2.0 & $(0.8$ & $3.0)$ & 1.0 & (0.0, & $3.0)$ & 0.337 \\
\hline $\begin{array}{l}\text { Craving } \\
\text { for snacks }\end{array}$ & 1.0 & $(0.0$ & $2.0)$ & 0.0 & $(0.0$ & 1.0) & 0.156 & 0.0 & $(0.0$ & 2.0) & 0.0 & $(0.0$ & $1.0)$ & 0.463 \\
\hline
\end{tabular}




\section{Discussion}

To our knowledge, this is the first study to clarify the differences in menstruationrelated symptoms before and during menstruation for university students living alone and university students living with their family. In this study, we found the intensity of menstruation-related symptoms before menstruation and during menstruation was stronger in students living alone than in students living with their family. In addition, the intensities of psychological symptoms, including negative affect and behavior change before and during menstruation and the degree of impaired concentration during menstruation, were stronger in students living alone, but the intensity of the physical symptoms was not significantly different between students living alone and students living with their family.

The intensity of the negative affect was stronger in students living alone than in students living with their family both before and during menstruation. It has been reported that the severity of psychological symptoms during menstruation was stronger in students living with their families than in students living alone, but physical and psychological symptoms were not associated with living status before menstruation [9]. The results of that suggested that, during a period of three months after starting university, students who had left their family home to live alone might be struggling to become independent and to take responsibility for managing their psychological conditions and relieving their symptoms [9]. The results of a survey for students in a different grade might be different. Another study that was conducted in April 2020, showed that the mental health level was not significantly different between either male or female students living alone and students living with someone [19]. It was reported that female students consult with family members, especially their mother, about menstruation and obtain information about menstruation [5,6]; however, it can be difficult for students living alone to receive such support from their family. This might be the reason for differences in menstruation-related symptoms being found according to living status.

Some reports have shown that the COVID-19 pandemic contributed to menstrual distress. In Ireland, the COVID-19 pandemic has had significant effects on the reproductive health of women, including an overall change in their menstrual cycle $(46 \%)$, worsening premenstrual symptoms (53\%) and the new appearance of dysmenorrhea (30\%) [12]. In a longitudinal study that was conducted before and during the pandemic for university students in Brazil, the investigation of the "anxiety/stress" symptom of the Premenstrual Symptoms Screening Tool (PSST) revealed that this symptom was more severe before the pandemic, and this can be due to the differences between urban dwellers and people living with families [20]. Another study conducted on 7143 Chinese male and female university students, showed that living with families/parents during the pandemic can be a protective factor against anxiety [21]. In the present study, there was no difference in the intensity of anxiety in the negative affect depending on living status. Anxiety in students might have decreased, given that more than 1 year has passed since the declaration of a pandemic. However, the intensity of mood swings before and during menstruation, the intensity of feeling sad or blue before menstruation and the intensity of crying and restlessness during menstruation were stronger in students living alone than in students living with their family. It was suggested that many Japanese university students living alone live in relatively small apartments, and that their opportunities for in-home exercise and new activities have been limited during the COVID-19 pandemic [19]. The living environment can have effects on the mental health and behavior in students living alone. Regarding behavior, we also found that students living alone had more behavioral changes than students living with their family. Before menstruation, the scores for behavior change, including taking naps, staying in bed, staying at home and avoiding social activities, were higher in students living alone than in students living with their family. A previous study showed that about half of Japanese female university students take naps, stay in bed, stay at home and avoid social activities before menstruation [16], suggesting that young women tend to be less active before menstruation. Another study showed that, regardless of the menstruation period, female university students living with their family tend to feel sleepiness more than 
students living alone, and they wake up earlier and have less sleeping time than students living alone [22]. This suggests that students with premenstrual symptoms may take more rest and that students who live alone can spend their time freely without being disturbed by others and behavioral changes, such as taking naps, staying in bed, staying at home and avoiding social activities, can occur easily.

It has been reported that living status was not associated with an increased craving for sweets and snacks in Japanese university female students [23]. However, we found that the degrees of increases in appetite and craving for sweets before menstruation were higher in students living alone than in students living with their family. We examined eating habits before and during menstruation, whereas Kasamaki et al. examined eating habits regardless of the menstrual period. This difference can be the reason for the different results regarding eating habits. It is necessary for female students living alone to understand the changes in eating habits during the menstrual period, since students living alone may have an increased craving for sweets and snacks before menstruation. We showed that BMI was higher in students living alone than in students living with their family. A previous study showed that BMI in female university students did not differ depending on living status [22]. Dietary constituents can be involved in the change in BMI because higher consumption of instant food and less consumption of vegetables in students living alone have been reported [22,23]. Students living alone should pay attention to appropriate eating habits.

A study conducted in April 2020 in Japanese university students, revealed that students who lived alone had lower levels of satisfaction with their studies and new activities than students living with someone [19]. We found that stress levels regarding study and academic performance were not different depending on living status. Since our study was conducted more than 1 year after the start of the COVID-19 pandemic, the different survey periods may have been the reason for the difference of results.

We found that the menstruation-related symptoms were more severe in students living alone than students in living with their family. It can be difficult for students living alone to consult with a family member, such as their mother or sister, about menstruation. Students living alone should make efforts to contact their family for advice.

There are several limitations in this study. First, since this study was a cross-sectional survey, a causal relationship during the COVID-19 pandemic could not be clarified. Second, the sample size was small and the participants were selected from only school of health sciences and from only one university. Thus, this study has a limitation regarding the generalizability of the findings. Third, the study might have recall bias by using a selfadministered questionnaire. Fourth, we showed data about different types of stresses including menstruation-related stress; therefore, potential interdependence may need a further investigation.

\section{Conclusions}

The present study showed that the Intensity of menstruation-related symptoms, degree of behavior change and intensity of craving for food before menstruation; the intensity of the negative affect before and during menstruation; and the intensity of impaired concentration during menstruation tend to be greater in students living alone than in students living with their family. From these results, we assume that the status of living alone can be related to intensifying some menstruation-related symptoms. However, as this study was cross-sectional study with limited sample size, we may need to conduct further studies with a larger sample size to support our assumption. Moreover, these results can imply that students who live alone need to be aware of the importance of talking about their menstruation problems with a family member, such as their mother or sister, for seeking advice.

Author Contributions: Y.M. and T.Y. conceptualized and designed the survey, collected and analyzed the data, and prepared and revised the manuscripts. N.H.T. revised and edited the manuscript. All authors have read and agreed to the published version of the manuscript. 
Funding: This study was supported by JSPS KAKENHI Grant Number JP20K10830.

Institutional Review Board Statement: The study was conducted in accordance with the guidelines of the Declaration of Helsinki and was approved by the Ethics Committee of Tokushima University Hospital (Approval No. 3932).

Informed Consent Statement: Informed consent was obtained from all subjects involved in the study by checking the button to agree to participate in the survey on the first page of the web survey before starting to answer.

Data Availability Statement: The data presented in this study are not publicly available because of privacy restrictions.

Acknowledgments: The authors would like to express their greatest appreciation to the participants.

Conflicts of Interest: The authors declare there are no conflict of interest.

\section{References}

1. Tadakawa, M.; Takeda, T.; Monma, Y.; Koga, S.; Yaegashi, N. The Prevalence and Risk Factors of School Absenteeism Due to Premenstrual Disorders in Japanese High School Students-a School-Based Cross-Sectional Study. Biopsychosoc. Med. 2016, 10, 13. [CrossRef]

2. Armour, M.; Parry, K.; Manohar, N.; Holmes, K.; Ferfolja, T.; Curry, C.; Macmillan, F.; Smith, C.A. The Prevalence and Academic Impact of Dysmenorrhea in 21,573 Young Women: A Systematic Review and Meta-Analysis. J. Women's Health 2019, 28, $1161-1171$. [CrossRef]

3. Ryu, A.; Kim, T.H. Premenstrual Syndrome: A Mini Review. Maturitas 2015, 82, 436-440. [CrossRef]

4. Otsuka-Ono, H.; Sato, I.; Ikeda, M.; Kamibeppu, K. Premenstrual Distress Among Japanese High School Students: Self-Care Strategies and Associated Physical and Psychosocial Factors. Women Health 2015, 55, 859-882. [CrossRef]

5. Armour, M.; Parry, K.; Al-Dabbas, M.A.; Curry, C.; Holmes, K.; MacMillan, F.; Ferfolja, T.; Smith, C.A. Self-Care Strategies and Sources of Knowledge on Menstruation in 12,526 Young Women with Dysmenorrhea: A Systematic Review and Meta-Analysis. PLoS ONE 2019, 14, e0220103. [CrossRef]

6. Chen, L.; Tang, L.; Guo, S.; Kaminga, A.C.; Xu, H. Primary Dysmenorrhea and Self-Care Strategies among Chinese College Girls: A Cross-Sectional Study. BMJ Open 2019, 9, e026813. [CrossRef] [PubMed]

7. Ferreira, K.S.; Guilherme, G.; Faria, V.R.; Borges, L.M.; Uchiyama, A.A.T. Women Living Together Have a Higher Frequency of Menstrual Migraine. Headache 2017, 57, 135-142. [CrossRef]

8. Abu Helwa, H.A.; Mitaeb, A.A.; Al-Hamshri, S.; Sweileh, W.M. Prevalence of Dysmenorrhea and Predictors of Its Pain Intensity among Palestinian Female University Students. BMC Women's Health 2018, 18, 18. [CrossRef]

9. Sakuma, Y.; Kanoya, Y.; Sato, C. The Effects of Changes in Lives of University Fresh Female Students on the Various Symptoms with Menstrual Cycles. Jpn. J. Matern. Health 2008, 49, 286-294. (In Japanese)

10. Clayton, A.H. Symptoms Related to the Menstrual Cycle: Diagnosis, Prevalence, and Treatment. J. Psychiatr. Pract. 2008, 14, 13-21. [CrossRef]

11. Perez-Dominguez, F.; Polanco-Ilabaca, F.; Pinto-Toledo, F.; Michaeli, D.; Achiardi, J.; Santana, V.; Urnelli, C.; Sawaguchi, Y.; Rodríguez, P.; Maldonado, M.; et al. Lifestyle Changes Among Medical Students During COVID-19 Pandemic: A Multicenter Study Across Nine Countries. Health Educ. Behav. 2021, 48, 446-454. [CrossRef]

12. Phelan, N.; Behan, L.A.; Owens, L. The Impact of the COVID-19 Pandemic on Women's Reproductive Health. Front. Endocrinol. 2021, 12, 642755. [CrossRef] [PubMed]

13. Nakamoto, M.; Kasanami, Y.; Tsuma, F.; Shinomiya, M. Relation among College Woman's Stress, Character, State, Uneasy Characteristic, and Premenstrual Syndrome. Jpn. J. Int. Nurs. Care Res. 2009, 8, 95-105. (In Japanese)

14. Yamashita, K.; Saito, M.; Takao, T. Stress and Coping Styles in Japanese Nursing Students. Int. J. Nurs. Pract. 2012, 18, $489-496$. [CrossRef]

15. Moos, R.H. The Development of a Menstrual Distress Questionnaire. Psychosom. Med. 1968, 30, 853-867. [CrossRef]

16. Matsumoto, T.; Egawa, M.; Kimura, T.; Hayashi, T. A Potential Relation between Premenstrual Symptoms and Subjective Perception of Health and Stress among College Students: A Cross-Sectional Study. Biopsychosoc. Med. 2019, 13, 26. [CrossRef] [PubMed]

17. Moos, R.H. Menstrual Distress Questionnaire Manual, Instrument, and Scoring Guide, 4th ed.; Mind Garden, Inc.: Menlo Park, CA, USA, 2010

18. Matsuura, Y.; Inoue, A.; Kidani, M.; Yasui, T. Change in Appetite and Food Craving during Menstrual Cycle in Young Students. Int. J. Nutr. Metab. 2020, 12, 25-30.

19. Tahara, M.; Mashizume, Y.; Takahashi, K. Mental Health Crisis and Stress Coping among Healthcare College Students Momentarily Displaced from Their Campus Community Because of COVID-19 Restrictions in Japan. Int. J. Environ. Res. Public Health 2021, 18, 7245. [CrossRef] [PubMed] 
20. Da Fonseca Freitas, F.; de Medeiros, A.C.Q.; de Araújo Lopes, F. Effects of Social Distancing During the COVID-19 Pandemic on Anxiety and Eating Behavior-A Longitudinal Study. Front. Psychol. 2021, 12, 645754. [CrossRef] [PubMed]

21. Cao, W.; Fang, Z.; Hou, G.; Han, M.; Xu, X.; Dong, J.; Zheng, J. The Psychological Impact of the COVID-19 Epidemic on College Students in China. Psychiatry Res. 2020, 287, 112934. [CrossRef] [PubMed]

22. Ichikawa, T. Effect of Living Environments on Lifestyles of Young Women Who Live Alone. J. Fac. Hum. Life Sci. Hiroshima Jogakuin Univ. 2012, 19, 51-59. (In Japanese)

23. Kasamaki, J.; Miyanishi, K.; Kasahara, Y.; Matsumoto, H.; Nishida, J.; Shibukura, T. Factors Related to Nutritional Intake in Students Attending Universities, Colleges, and Vocational Schools: Focus on Gender and Household Living Arrangement. Jpn. J. Hyg. 2018, 73, 395-412. (In Japanese) [CrossRef] [PubMed] 